\title{
A comparison of two common sample preparation techniques for lipid and fatty acid analysis in three different coral morphotypes reveals quantitative and qualitative differences
}

\author{
Jessica A Conlan ${ }^{\text {Corresp., }}{ }^{1,2}$, Melissa M Rocker ${ }^{3}$, David S Francis ${ }^{1,2}$ \\ ${ }^{1}$ School of Life and Environmental Sciences, Deakin University, Warrnambool, Victoria, Australia \\ 2 Australian Institute of Marine Science, Townsville, Queensland, Australia \\ 3 School of Life and Environmental Sciences, Deakin University, Geelong, Victoria, Australia \\ Corresponding Author: Jessica A Conlan \\ Email address: conlan@deakin.edu.au
}

Lipids are involved in a host of biochemical and physiological processes in corals. Therefore, changes in lipid composition reflect changes in the ecology, nutrition, and health of corals. As such, accurate lipid extraction, quantification, and identification is critical to obtain comprehensive insight into a coral's condition. However, discrepancies exist in sample preparation methodology globally, and it is currently unknown whether these techniques generate analogous results. This study compared the two most common sample preparation techniques for lipid analysis in corals: 1) tissue isolation by airspraying and 2) crushing the coral in toto. Samples derived from each preparation technique were subsequently analysed to quantify lipids and their constituent classes and fatty acids in four common, scleractinian coral species representing three distinct morphotypes (Acropora millepora, Montipora crassotuberculata, Porites cylindrica, and Pocillopora damicornis). Results revealed substantial amounts of organic material, including lipids, retained in the skeletons of all species following air-spraying, causing a marked underestimation of total lipid concentration using this method. Moreover, lipid class and fatty acid compositions between the denuded skeleton and sprayed tissue were substantially different. In particular, the majority of the total triacylglycerol and total fatty acid concentrations were retained in the skeleton (55-69\% and $56-64 \%$, respectively). As such, the isolated, sprayed tissue cannot serve as a reliable proxy for lipid quantification or identification in the coral holobiont. The in toto crushing method is therefore recommended for coral sample preparation prior to lipid analysis to capture the lipid profile of the entire holobiont, permitting accurate diagnoses of coral condition. 
1 A comparison of two common sample preparation techniques for lipid and fatty

2 acid analysis in three different coral morphotypes reveals quantitative and

3 qualitative differences

4

5 Jessica A. Conlan ${ }^{1,2, *}$, Melissa M. Rocker ${ }^{3}$, and David S. Francis ${ }^{1,2}$

$7 \quad{ }^{1}$ School of Life and Environmental Sciences, Deakin University, Warrnambool, Victoria,

8 Australia

$9 \quad{ }^{2}$ Australian Institute of Marine Science, Townsville, Queensland, Australia

$10 \quad{ }^{3}$ School of Life and Environmental Sciences, Deakin University, Geelong, Victoria, Australia 11

$12{ }^{*}$ Corresponding author Jessica Conlan (conlan@deakin.edu.au)

13

14 


\section{Abstract}

17 Lipids are involved in a host of biochemical and physiological processes in corals. Therefore, 18 changes in lipid composition reflect changes in the ecology, nutrition, and health of corals. As

19 such, accurate lipid extraction, quantification, and identification is critical to obtain

20 comprehensive insight into a coral's condition. However, discrepancies exist in sample

21 preparation methodology globally, and it is currently unknown whether these techniques

22 generate analogous results. This study compared the two most common sample preparation

23 techniques for lipid analysis in corals: 1) tissue isolation by air-spraying and 2) crushing the

24 coral in toto. Samples derived from each preparation technique were subsequently analysed to

25 quantify lipids and their constituent classes and fatty acids in four common, scleractinian coral

26 species representing three distinct morphotypes (Acropora millepora, Montipora

27 crassotuberculata, Porites cylindrica, and Pocillopora damicornis). Results revealed substantial

28 amounts of organic material, including lipids, retained in the skeletons of all species following

29 air-spraying, causing a marked underestimation of total lipid concentration using this method.

30 Moreover, lipid class and fatty acid compositions between the denuded skeleton and sprayed

31 tissue were substantially different. In particular, the majority of the total triacylglycerol and total

32 fatty acid concentrations were retained in the skeleton (55-69\% and 56-64\%, respectively). As

33 such, the isolated, sprayed tissue cannot serve as a reliable proxy for lipid quantification or

34 identification in the coral holobiont. The in toto crushing method is therefore recommended for

35 coral sample preparation prior to lipid analysis to capture the lipid profile of the entire holobiont,

36 permitting accurate diagnoses of coral condition. 


\section{Introduction}

39 Coral reefs worldwide are declining at an alarming pace due to the increasing diversity,

40 frequency, and scale of human impacts (Lesser, 2012; Hughes et al., 2017). Consequently, the

41 urgency and prevalence of internationally-integrated research supporting coral reef management,

42 rehabilitation, and aquaculture efforts has increased (Leal et al., 2016).

43 Scleractinian corals are commonly used as biomonitors for phenological and ecological

44 phenomena in tropical reef ecosystems, given their high sensitivity to physical and chemical

45 changes in the marine environment (Goffredo et al., 2011; Filho et al., 2012). Specifically, coral

46 lipid reserves serve as a universal proxy for coral health status given their ubiquitous nature

47 (Anthony et al., 2009; Lesser, 2012). Lipids are a major component of the coral proximate composition (10-40\% of dry biomass) and their constituent classes and fatty acids play important

49 roles in energy storage, cell membrane structure, and overall fitness (Bergé \& Barnathan, 2005;

50 Farre, Cuif \& Dauphin, 2010). The quantity and nature of coral lipids vary significantly in

51 response to environmental factors such as season and food availability, as well as with

52 physiological processes such as photosynthesis, respiration, and reproduction (Arai et al., 1993;

53 Imbs, 2013). As such, lipid analysis is an important and prevalent aspect of coral biology, with

54 over 560 publications relating to coral lipids published since 1970 (ISI Web of Science).

Likewise, coral lipid investigations are gaining momentum as tools for understanding current and future climate change impacts on coral reefs, since total lipid content has been shown to determine a coral's ability to offset the adverse responses to climate change-associated stressors

58 (Baumann et al., 2014; Towle, Enochs \& Langdon, 2015). For example, large lipid stores can mitigate growth reductions caused by reduced photosynthate transfer as well as greater energy

60 demands on calcification in response to ocean warming and acidification (Baumann et al., 2014; 
61 Towle, Enochs \& Langdon, 2015). Additionally, the size of a coral's lipid stores have been

62 shown to significantly influence the onset timing of severe bleaching and subsequent mortality.

63 Indeed, under high bleaching rates, corals with 'full' initial lipid stores have been shown to

64 survive for twice as long as corals with half-depleted lipid stores (Anthony et al., 2009).

65 Moreover, examining the corals' lipid class and fatty acid composition in addition to the total

66 lipid content evidences key metabolic changes elicited by bleaching, and thus determine a corals'

67 ability to initially resist bleaching, followed by the timing and capacity for full recovery

68 (Rodrigues, Grottoli \& Pease, 2008).

69 Therefore, accurate quantification and subsequent identification of coral lipids and their

70 constituents is of significant importance to their reliability as biomarkers of coral health and their

71 capacity to predict the timing and severity of major stress events associated with climate change.

72 However, within the literature, discrepancies exist between sample preparation techniques prior

73 to lipid analysis, and it is currently unknown whether these techniques generate analogous

74 results.

75 The two most common techniques for coral sample preparation prior to lipid analyses are air76 spraying and in toto crushing. The first, air-spraying, is a modified version of the Water-Pik

77 method described by Johannes \& Wiebe (1970). This method involves completely removing the

78 tissue from the coral skeleton using an airgun connected to a source of compressed air inside a

79 thick, polyethylene bag (Deschaseaux et al., 2013). The sprayed tissue is collected in the bag and

80 combined with filtered seawater to form a slurry that is then homogenised, frozen, and freeze-

81 dried to obtain the tissue alone. This tissue isolate is then extracted for lipids, excluding the

82 denuded skeleton (Szmant \& Gassman, 1990). Air-spraying presents a flexible option, since the

83 resultant isolates can be used for further biometrics such as zooxanthellae counting (tissue) 
84 (Edmunds \& Gates, 2002) and surface area measurements (skeleton) (Veal et al., 2010). This

85 technique also ensures that the samples are maximally utilised, since conservative coral sampling

86 is often necessary to limit environmental impacts on donor reefs and reduce associated collection

87 expenses. As such, performing lipid analyses on the isolated coral tissue alone remains prevalent

88 in coral biochemical research (e.g. Seemann et al. 2013; Towle et al. 2015; Crandall et al. 2016;

89 Lim et al. 2017).

90 The second method, in toto crushing, utilises the coral as a whole; crushing the intact skeleton

91 and tissue while frozen within a mortar and pestle, and using the resultant powder for lipid

92 analyses (Saunders et al., 2005; Deschaseaux et al., 2013). Crushing takes into consideration the

93 presence of the 'skeletal organic material' (SOM) that is integrated throughout the skeleton. This

94 includes the skeletal organic matrix, which controls skeletal growth by inducing or inhibiting

95 biomineral crystal nucleation (Allemand et al., 1998; Farre, Cuif \& Dauphin, 2010; Hemond,

96 Kaluziak \& Vollmer, 2014), the gastrovascular system (Parrin et al., 2010), and other organic

97 material such as entrapped tissue and zooxanthellae (Tambutté et al., 2007). Importantly, SOM

98 in the skeleton has been shown to differ biochemically from the tissue (Dauphin, Cuif \&

99 Massard, 2006; Ramos-Silva et al., 2014). However, comprehensive quantification and

100 identification of lipids isolated in the tissue and those retained by the skeleton does not exist.

101 Thus, it is not yet known whether isolated tissue obtained with the air-spraying technique

102 accurately represents the lipid quantity and composition of the whole coral. This reduces the

103 reliability of lipids as a biomarker of several aspects of coral health, including reproductive

104 status, growth, nutritional integrity, response to environmental change, and overall fitness,

105 potentially leading to inaccurate diagnoses of coral condition. This, in turn, can lead to

106 inadequate or inappropriate decisions relating to reef management, jeopardising the success of 
107 coral monitoring, rehabilitation, and aquaculture efforts. Furthermore, discrepancies between

108 sample preparation techniques limits the ability for direct comparison between studies, reducing

109 the efficiency of global investigations.

110 Here, we explore and compare the performance of these two sample preparation methods to

111 determine their effectiveness for accurate lipid, lipid class, and fatty acid (FA) analyses of the

112 coral holobiont. In order to show the applicability of each method for different coral

113 morphotypes, we tested four common coral genera with three different skeletal and tissue

114 morphologies: Acropora millepora and Porites cylindrica; representing perforate, branching

115 species, Montipora crassotuberculata; representing perforate, plate forming species, and

116 Pocillopora damicornis; representing imperforate, branching species. Where differences

117 between the two methods were detected, their causes and ramifications are discussed.

119 Materials and Methods

120 Sample collection

121 Forty coral nubbins ( $\sim$ length $5 \mathrm{~cm})$ from each of four species of common scleractinian genera;

122 Acropora millepora, Montipora crassotuberculata, Porites cylindrica, and Pocillopora

123 damicornis, were collected from the Great Barrier Reef, Queensland, Australia between the 18-

$12419^{\text {th }}$ of April 2015 (three genotypes species ${ }^{-1}$ ) (Field collections were approved by the Great

125 Barrier Reef Marine Park Authority: G12/35236.1). M. crassotuberculata were collected from

126 Pelorus Island (lat.: $18^{\circ} 548^{\prime}$ S, long.: $146^{\circ} 504^{\prime} \mathrm{E}$ ). All other species were collected from Davies

127 Reef from two sites (lat.: $18^{\circ} 496^{\prime}$ S, long.: $147^{\circ} 376^{\prime} \mathrm{E}$ and lat.: $18^{\circ} 499^{\prime}$ S, long.: $147^{\circ} 379^{\prime} \mathrm{E}$ ).

128 Corals were then transferred to the National Sea Simulator facility at The Australian Institute of

129 Marine Science (AIMS, Townsville, Australia, lat.: $16^{\circ} 177^{\prime}$ S, long.: $145^{\circ} 271^{\prime}$ E). 


\section{Sample preparation}

132 All nubbins were weighed prior to sample preparation. For each species, 20 nubbins were

133 prepared with the air-spraying method as described by Szmant \& Gassman (1990). Tissue was

134 removed from the coral skeleton using a jet of high-pressure air from a hand gun $(80 \mathrm{psi}, \sim 1 \mathrm{~cm}$

135 distance to coral). All sprayed tissue was captured in a thick, polyethylene bag containing $10 \mathrm{ml}$

136 of ultrafiltered seawater $(0.04 \mu \mathrm{m}$ filtration). Nubbins were sprayed scrupulously for 10 minutes,

137 ensuring that all surface tissue was removed, as confirmed visually by the completely white

138 surface of the denuded skeletons. To further ensure that no surface tissue remained, the denuded

139 skeletons were triple-rinsed in ultrafiltered seawater, which was also collected. The tissue slurry

140 was then poured from the plastic bag into a falcon tube, and the bag was double-rinsed with

141 ultrafiltered seawater that was also collected. The slurry was then homogenised for 20 seconds

142 (Ultra-Turrax T10B, IKA Labortechnik). The isolated tissue and denuded skeletons were then re-

143 weighed separately in order to quantify their individual proximate parameters, and individual

144 contribution to the total composition. The denuded skeletons were kept and subjected to all

145 analyses alongside the isolated tissue and in toto samples. Following this, the sprayed tissue and

146 denuded skeleton results were recombined ex post facto in order to account for any discrepancies

147 detected between the air-spraying method (isolated tissue only) and the in toto crushing method.

148 Between each sample, all apparatus were thoroughly cleaned with methanol $\left(\mathrm{CH}_{3} \mathrm{OH}\right)$ and rinsed

149 with seawater. The remaining 20 nubbins from each species were left untreated and these, along

150 with the tissue slurry and denuded skeletons, were frozen at $-20^{\circ} \mathrm{C}$. All samples were then freeze-

151 dried for $96 \mathrm{~h}$ (Labconco FreeZone, Kansas City, MO, USA), removing all moisture from the

152 tissue slurry. Following freeze-drying, both the denuded and intact skeleton samples were placed 
153 inside a stainless steel mortar and pestle (cleaned with methanol), which was placed inside a

154 manual laboratory hydraulic press (Model C, Fred S. Carver Inc., Summit, NJ, USA), and

155 pressurised to $70 \mathrm{kN}$, crushing the corals to a fine powder.

156

157 Proximate analysis

158 Total lipid and ash

159 The tissue isolate, denuded skeleton, and intact samples were extracted for total lipid content

160 according to the method described in Conlan et al. (2014). Dry samples were soaked overnight in

$1613 \mathrm{~mL}$ of dichloromethane: methanol $\left(\mathrm{CH}_{2} \mathrm{Cl}_{2}: \mathrm{CH}_{3} \mathrm{OH}\right)$. The following morning, this mixture was

162 filtered and the solid residue re-suspended and further soaked for $10 \mathrm{~min}$ with $3 \mathrm{~mL}$ of

$163 \mathrm{CH}_{2} \mathrm{Cl}_{2}: \mathrm{CH}_{3} \mathrm{OH}$, followed by a further filtration step. This process was repeated three times. The

164 combined filtrates $(\sim 9 \mathrm{~mL})$ were then combined with $4.5 \mathrm{~mL}$ of $\mathrm{KCl}(0.44 \%)$ in $\mathrm{H}_{2} \mathrm{O} / \mathrm{CH}_{3} \mathrm{OH}$

$165(3: 1, \mathrm{v} / \mathrm{v})$, shaken vigorously and settled overnight. The following morning, the bottom layer

166 containing the extracted lipid was recovered $(\sim 2.5 \mathrm{~mL})$ and the solvent was evaporated under

167 nitrogen. The lipid content was then quantified gravimetrically on a 4-figure balance (Mettler-

168 Toledo, AB 204, Greifensee, Switzerland).

169 Total ash was determined by incineration in a muffle furnace (C \& L Fetlow, Model WIT,

170 Blackburn, Victoria, Australia) at $450^{\circ} \mathrm{C}$ for $12 \mathrm{~h}$. The ash content was subtracted from the total

171 composition to obtain ash-free dry weight (AFDW), which excludes the inorganic component.

\section{Lipid class composition}

173 Lipid class analysis was determined using an Iatroscan MK 6s thin layer chromatography-flame

174 ionisation detector (Mitsubishi Chemical Medience, Tokyo, Japan) according to the method of

175 Conlan et al. (2014). Each sample was spotted in duplicate on silica gel S5-chromarods $(5 \mu \mathrm{m}$ 
176 particle size) with lipid separation following a two-step elution sequence: 1) elution of

177 phosphatidylethanolamine (PE), phosphatidylserine and phosphatidylinositol (PS-PI),

178 phosphatidylcholine (PC), and lysophosphatidylchloline (LPC) was achieved in a

$179 \mathrm{CH}_{2} \mathrm{Cl}_{2}: \mathrm{CH}_{3} \mathrm{OH}: \mathrm{H}_{2} \mathrm{O}$ (50:20:2, by volume) solvent system run to half height ( $\left.15 \mathrm{~min}\right)$; and 2)

180 after air drying, elution of wax esters (WAX), triacylglycerol (TAG), free fatty acid (FFA), 1,2-

181 diacylglycerol (1,2DAG), and sterol (ST) was achieved in a $\mathrm{C}_{16} \mathrm{H}_{14}:\left(\mathrm{C}_{2} \mathrm{H}_{5}\right)_{2} \mathrm{O}: \mathrm{CH}_{2} \mathrm{O}_{2}(60: 15: 1.5$,

182 by volume) solvent system run to full height ( $\sim 30 \mathrm{~min})$. Since glycolipids commonly elute with

183 monoacylglycerols and pigments, the term "acetone mobile polar lipid" (AMPL) was used

184 (Parrish, Bodennec \& Gentien, 1996). AMPL was quantified using the 1-monopalmitoyl glycerol

185 standard (Sigma-Aldrich Co., USA), which has demonstrated a response that is intermediate

186 between glycoglycerolipids and pigments (Parrish, Bodennec \& Gentien, 1996).

Fatty acid and fatty alcohol composition

189 Acid catalysed methylation

190 Following extraction, FA were esterified into methyl esters using the acid catalysed methylation

191 method (Christie, 2003). $100 \mu \mathrm{L}$ of 23:0 $\left(0.75 \mathrm{mg} \mathrm{mL}^{-1}\right)$ was added as an internal standard

192 (Sigma-Aldrich, Inc., St. Louis, MO, USA) alongside $2 \mathrm{~mL}$ of freshly prepared $\mathrm{CH} 3 \mathrm{COCl}$ :

$193 \mathrm{CH}_{3} \mathrm{OH}(1: 10, \mathrm{v} / \mathrm{v})$. Sample vials were then shaken and placed in an oven at $100^{\circ} \mathrm{C}$ for $1 \mathrm{~h}$. Once

194 cool, $2 \mathrm{~mL}$ of $\mathrm{K}_{2} \mathrm{CO}_{3}(1 \mathrm{M})$ and $1.7 \mathrm{~mL}$ of $\mathrm{C}_{16} \mathrm{H}_{14}$ were added and the sample centrifuged. The

$195 \mathrm{C}_{16} \mathrm{H}_{14}$ supernatant was then recovered and placed in a vial for subsequent gas chromatograph

196 (GC) injection.

197 
198 Gas chromatography

199 FA methyl esters were identified using an Agilent Technologies 7890A GC System (Agilent

200 Technologies; Santa Clara, CA, USA $)$ equipped with a BPX70 capillary column $(120 \mathrm{~m} \times 0.25$

$201 \mathrm{~mm}$ internal diameter, $0.25 \mu \mathrm{m}$ film thickness, SGE Analytical Science, Ringwood, VIC,

202 Australia), a flame ionization detector (FID), an Agilent Technologies 7693 auto sampler, and a

203 splitless injection system. The injection volume was $1 \mu \mathrm{L}$ and the injector and detector

204 temperatures were $300^{\circ} \mathrm{C}$ and $270^{\circ} \mathrm{C}$, respectively. The temperature program was $60^{\circ} \mathrm{C}$ held for 2

$205 \mathrm{~min}$, then from $60^{\circ} \mathrm{C}$ to $150^{\circ} \mathrm{C}$ at $20^{\circ} \mathrm{C} \mathrm{min}-1$, and held at $150^{\circ} \mathrm{C}$ for $2 \mathrm{~min}$, then from $150^{\circ} \mathrm{C}$ to

$206205^{\circ} \mathrm{C}$ at $1.5^{\circ} \mathrm{C} \mathrm{min}^{-1}$, then from $205^{\circ} \mathrm{C}$ to $240^{\circ} \mathrm{C}$ at $5^{\circ} \mathrm{C} \mathrm{min}{ }^{-1}$, and held at $240^{\circ} \mathrm{C}$ for $24 \mathrm{~min}$. The

207 carrier gas was helium at a constant flow of $1.5 \mathrm{~mL} \mathrm{~min}^{-1}$. Each $\mathrm{FA}$ was identified relative to

208 known external standards (Sigma-Aldrich, Inc., St. Louis, MO, USA and Nu-Chek Prep Inc.,

209 Elysian, MN, USA), using GC ChemStation (Rev B.04.03; Agilent Technologies; Santa Clara,

210 CA, USA). The resulting peaks were then corrected by theoretical relative FID response factors

211 (Ackman, 2002) and quantified relative to the internal standard.

\section{Statistical analysis}

213 Untransformed data were analysed statistically using RStudio (RStudio Team, 2015; R

214 Development Core Team, 2016). For between-group comparisons (tissue vs skeleton), a Welch

215 Two-Sample t-test was used, at a 0.05 significance level. Although data were non-normal and

216 slightly skewed to the right, the t-test was considered robust given the moderate sample size

217 ( $\mathrm{n}=20)$ (Lumley et al., 2002). Principal component analysis (PCA) was also performed to reduce

218 and group 20 individual FA (expressed as \% total FA) to more concisely explain and visualise

219 overall variation (Kassambara \& Mundt, 2016). PCA ellipses show 95\% confidence intervals.

220 Graphs were prepared using the ggplot2 package (Wickham, 2009). 


\section{Results}

\section{Proximate composition}

224 Based on dry weight, the intact crushing method showed that the large majority of the holobiont

225 consisted of ash in all species ( $\sim 944-954 \mathrm{mg} \mathrm{g}$ dry sample $\left.^{-1}\right)$, while the organic fraction

226 constituted only a small portion ( 46.2-66.1 mg g dry sample $\left.{ }^{-1}\right)$. A. millepora contained the

227 highest total lipid concentration $\left(9.93 \pm 0.64 \mathrm{mg} \mathrm{g} \mathrm{sample}^{-1}\right)$, while $P$. damicornis recorded the

228 lowest $\left(2.74 \pm 0.22 \mathrm{mg} \mathrm{g} \mathrm{sample}{ }^{-1}\right)$ (Table 1$)$.

229 Recombining the sprayed tissue and denuded skeleton results from the air-spraying method ex

230 post facto revealed significant loss of tissue, and consequently lipid, when compared to the intact

231 samples, with $A$. millepora, M. crassotuberculata, and $P$. damicornis recording a loss of $\sim$ one

232 third, and P. cylindrica $\sim$ one quarter of the total lipid. Conversely, no difference was detected in

233 the ash content between the two samples.

234 Comparing the two isolates alone showed, unsurprisingly, that the denuded skeleton accounted

235 for the large majority of the total sample ( 960-989 $\mathrm{mg} \mathrm{g}^{\mathrm{g}}$ sample $\left.{ }^{-1}\right)$ (Table 1$)$. The majority of

236 the total organic material was retained in the denuded skeleton, and this was quantitatively

237 similar across all genera ( 33.9-36.6 $\left.\mathrm{mg} \mathrm{g} \mathrm{sample}^{-1}\right)$ (Table 1). The relative contribution of the

238 skeleton to the total organic fraction was highest for P. damicornis ( 83.6\%), and lowest for $A$.

239 millepora $(\sim 63.2 \%)$ (Table 1$)$. On the other hand, the concentrations of organic material in the

240 tissue varied between genera, with $A$. millepora recording the highest $\left(21.3 \pm 2.20 \mathrm{mg} \mathrm{g} \mathrm{sample}^{-1}\right)$

241 ( $\sim 37 \%$ of total), and P. damicornis the lowest $\left(6.72 \pm 1.30 \mathrm{mg} \mathrm{g} \mathrm{sample}^{-1}\right)(\sim 16 \%$ of total).

242 The relative contribution of total lipid from each isolate was remarkably consistent between $A$.

243 millepora, M. crassotuberculata, and P. damicornis ( $\sim 2 \%$ skeleton, $\sim 58 \%$ tissue), although the 
244 quantitative amounts differed ( 0.76-2.62 $\mathrm{mg} \mathrm{g} \mathrm{sample}^{-1}$ skeleton, and $\sim 1.04-3.58 \mathrm{mg} \mathrm{g} \mathrm{sample} \mathrm{e}^{-1}$

245 tissue). Meanwhile, $P$. cylindrica contained almost equal amounts of the total lipid concentration

246 in the skeleton and tissue (1.26 \pm 0.30 and $1.24 \pm 0.30 \mathrm{mg} \mathrm{g} \mathrm{sample}{ }^{-1}$, respectively).

\section{Lipid class composition}

249 Intact vs. recombined samples

250 The lipid class composition of the intact samples showed the storage component of all species to

251 be dominated by TAG, followed by WAX (Table 2). P. cylindrica was an exception, exhibiting

252 comparatively low TAG concentrations. This translated to the total storage lipid for this species

$253\left(307 \pm 23.9 \mathrm{mg} \mathrm{g} \mathrm{lipid}^{-1}\right)$, which was low compared to the other species $\left(\sim 375-433 \mathrm{mg} \mathrm{g} \mathrm{lipid}^{-1}\right)$.

254 For all genera, the polar lipids were dominated by AMPL, PE, PS-PI, and PC.

255 Recombining the sprayed tissue and denuded skeleton results from the air-spraying method ex

256 post facto showed some discrepancies when compared to the intact samples for all species. In

257 particular, there were significantly higher concentrations of FFA and lower PE and LPC in the

258 intact samples compared to the recombined for A. millepora, significantly lower FFA in the

259 intact samples compared to the recombined for M. crassotuberculata, significantly higher PSPI

260 in the intact compared to the recombined for P. cylindrica, and significantly lower AMPL and

261 higher LPC in the intact compared to the recombined for P. damicornis $(\mathrm{P}<0.05)$.

262 Tissue vs. skeleton - relative contribution

263 A. millepora, M. crassotuberculta, and P. damicornis contained significantly higher proportions

264 of ST in the tissue $(\mathrm{P}<0.05)$ (Fig. 1). These species also contained higher levels of AMPL and all

265 individual phospholipids in the tissue, however, the former was only significant for $A$. millepora

266 and $M$. crassotuberculata, and the latter only for $A$. millepora $(\mathrm{P}<0.05)$. Meanwhile, $P$. 
267 cylindrica contained significantly higher amounts of ST in the skeleton compared to the tissue $268(\mathrm{P}<0.05)$. For all genera, the majority of WAX and TAG occurred in the skeleton, and the latter

269 was significant for A. millepora and P. damicornis $(\mathrm{P}<0.05)$.

270

271 Fatty acid and fatty alcohol composition

272 Intact vs. recombined samples

273 The total FA concentration was highest in A. millepora and P. cylindrica (33.4 \pm 9.42 and

$27434.9 \pm 8.52 \%$ lipid, respectively) (Table 3), followed by M. crassotuberculata $(30.0 \pm 9.78 \%$

275 lipid), while P. damicornis contained the lowest (25.8 $\pm 10.3 \%$ lipid). All genera were dominated 276 by SFA ( $\sim 50 \%$ FA), followed by PUFA ( $\sim 20-30 \%$ FA), and MUFA ( $11-15 \%$ FA). The

277 dominant SFA was 16:0 for all species ( $25-38 \%$ FA), while 18:1n-9 was the major MUFA for 278 all species except M. crassotuberculata, which contained similar amounts of $20: 1 \mathrm{n}-11$. The 279 dominant PUFA were species-specific, being 20:5n-3 (EPA) for A. millepora, 22:4n-6 for $M$. 280 crassotuberculata and $P$. cylindrica, and 22:6n-3 (DHA) for $P$. damicornis.

281 Due to the quantitative loss in total lipid content, recombining the sprayed tissue and denuded

282 skeleton results from the air-spraying method ex post facto showed correspondingly lower 283 amounts of all individual FA compared to the intact samples. The total FA concentration (\%

284 lipid) was significantly higher in the intact samples compared to the recombined for all species 285 except $P$. damicornis $(\mathrm{P}<0.05)$. Furthermore, all species contained significantly higher 286 proportions of PUFA in the intact samples compared to the recombined (\% FA). On the other 287 hand, all species contained higher proportions of SFA in the recombined samples compared to 288 the intact, and this was statistically significant for A. millepora and P. cylindrica $(\mathrm{P}<0.05)$. The 289 individual FA, EPA and DHA exhibited higher concentrations in the intact samples compared to 
290 the recombined, and the former was statistically significant for all species except $M$.

291 crassotuberculata, while the latter was significant for A. millepora and $P$. cylindrica $(\mathrm{P}<0.05)$.

292

293 Tissue vs. skeleton - relative contribution

294 The total FA (\% total) proportion was greatest in the skeleton for all genera $(\sim 56-64 \%)$, and was

295 significant compared to the tissue for $P$. cylindrica and P. damicornis $(\mathrm{P}<0.05)$ (Fig. 2).

296 Generally, the major FA groups were dispersed uniformly between the skeleton and tissue.

297 However, for A. millepora, there were significantly higher proportions of PUFA in the tissue

298 ( $55 \%)$, while P. cylindrica contained a higher proportion of PUFA in the skeleton $(\sim 56 \%)$

$299(\mathrm{P}<0.05)$.

300

301 Principal components

302 Both groups were separated fairly well along the first two principal components, which described

303 a large proportion of the data (A. millepora: $76.4 \%$, M. crassotuberculata: $54.0 \%$, P. damicornis:

$30464.0 \%$, P. cylindrica: $60.1 \%$ ) (Fig. 3). For all species, 16:0 was a major contributor to the

305 separation of the skeleton from the tissue, being largely retained by the skeleton (Fig. 4). The

306 fatty alcohol, 16:OH, along with 21:0, 20:1n-11, and EPA, were more strongly associated with

307 the tissue for all species. The major contributor to the second principal component was DHA for

308 A. millepora, P. cylindrica, and P. damicornis. 


\section{Discussion}

311 The present study evaluated the comparative efficacy of two sample preparation methods of

312 scleractinian corals for accurate lipid and FA analysis. Lipids and their constituent classes and

313 FA play important roles in coral energy storage, cell membrane structure, and overall fitness

314 (Bergé \& Barnathan, 2005; Farre, Cuif \& Dauphin, 2010). As such, lipid analysis is an important

315 and prevalent aspect of coral biology, and the use of accurate and ubiquitous methodology in

316 coral biochemistry ensures that subsequent actions in coral monitoring, rehabilitation, and

317 aquaculture efforts are appropriate and well-informed.

318 Recombining the sprayed tissue and denuded skeleton ex post facto and comparing with the

319 intact samples revealed significant tissue and hence lipid loss across all samples prepared with

320 the air-spraying technique (Table 1). This loss likely occurred during the additional steps

321 required by this method, increasing the risk of tissue loss through residue on apparatus, including

322 the airgun nozzle, polyethylene bag, and homogeniser shaft, despite thorough rinsing.

323 Additionally, the increased handling time increases the risk of lipid oxidation through excessive

324 air exposure, potentially altering the lipid profile. Lipid oxidation is also a major drawback of

325 some alternative, rarefied methods of coral lipid extraction. For example, the process of

326 decalcifying the coral skeleton with an acetic acid solution (e.g. Yamashiro et al. 1999;

327 Rodríguez-Troncoso et al. 2011) is likely to elicit major alteration of the lipid profile, since

328 acetic acid has been shown to cause significant lipid oxidation and fatty acid hydrolysis (Sajiki,

329 Takahashi \& Takahashi, 1995). Additionally, the gravimetric calculation method of soaking the

330 oven-dried coral in toto in an organic solvent and re-weighing the re-dried skeleton to quantify

331 total lipids (e.g. Ward 1995; Pisapia et al. 2014) involves excessive sample handling and

332 exposure to heat - greatly increasing the risk of lipid degradation and rendering this technique 
333 unusable for qualitative analyses. In contrast, the in toto crushing method used in the present

334 study requires far less sample handling and laboratory equipment, preserving the integrity of the

335 lipid profile. Moreover, intact skeletons are only processed once freeze-dried and re-frozen,

336 minimising the risk of oxidation and making residue easy to recover.

337 In addition to lipid loss, the results conclusively demonstrate that the large majority of the coral's

338 total organic fraction is retained in the skeleton for all genera, including almost half the total

339 lipid concentration (Table 1). This is despite scrupulously air-spraying the skeletons for ten

340 minutes until they were uniformly white, and triple-rinsing the sprayed skeletons in seawater in

341 an attempt to completely denude the skeletons of organic material. As such, excluding the

342 denuded skeleton and analysing the isolated tissue alone for proximate composition incurs a

343 significant underestimation of the total organic content and subsequent lipid concentration of the

344 coral holobiont. Moreover, since lipid only constituted 2.5-8.7\% of the total organic material

345 (Table 1), the majority of the organic material recorded in both the skeleton and tissue went

346 unclassified. This remaining portion likely consists of protein, amino acids, and carbohydrates,

347 which are prevalent in a coral's organic fraction (Dauphin \& Cuif, 1997; Allemand et al., 1998).

348 Clearly, the total concentration of these compounds would also be severely underestimated using

349 the air-spraying method. However, these represent critical nutrients in coral life functions since

350 protein fuels tissue growth and calcification, while carbohydrates represent a quickly-mobilised

351 energy source that sustain coral metabolism (Oku et al., 2002; Ramos-Silva et al., 2014). As

352 such, this method can be deemed inappropriate not only for lipid analyses, but all proximate

353 analyses.

354 The relative partitioning of structural complexity is different among the four morphotypes

355 investigated. In particular, the genera, Acropora, Montipora, and Porites grow perforate 
356 skeletons with a relatively simple external structure, yet great internal complexity (Dauphin, Cuif

357 \& Massard, 2006; Farre, Cuif \& Dauphin, 2010; Work \& Aeby, 2010; Yost et al., 2013). The

358 internal complexity of perforate corals is largely comprised of the intricate gastrovascular

359 system, which penetrates deep into the skeleton and forms a three-dimensional environment for

360 the dispersion of symbionts and organic matter (Hii, Soo \& Liew, 2008; Veal et al., 2010; Work

361 \& Aeby, 2010; Davy, Allemand \& Weis, 2012). In some cases, pockets of skeletal tissue are

362 completely confined by the skeleton, and this internal tissue network cannot realistically be

363 evacuated through the use of air-spraying.

364 On the other hand, the Pocillopora genus is known to produce imperforate skeletons, possessing

365 only a thin layer of external tissue (Yost et al., 2013). Therefore, the persistence of $>80 \%$ of the

366 total organic material in the $P$. damicornis skeleton, including $42 \%$ of the total lipids, was

367 surprising. However, this is likely attributable to two factors: Firstly, branching imperforate

368 corals such as $P$. damicornis exhibit high levels of external structural complexity, including

369 immersed corallites (Veron, 2000), compared to perforate genera (Yost et al., 2013). This

370 external structural complexity impedes the ability of air-spraying to completely denude the

371 skeleton, despite the rigorous and standardised application of the method.

372 Residual surface tissue has previously been demonstrated using the Water-Pik method (see

373 Johannes \& Wiebe 1970) in both perforate (Bachok, Mfilinge \& Tsuchiya, 2006) and

374 imperforate (Brahmi et al., 2012) coral skeletons. Additionally, the Water-Pik method does not

375 entirely remove thick, fibrous mesoglea, including zooxanthellae, in several coral genera,

376 including Montipora, Pocillopora, and Porites (Johannes \& Wiebe, 1970). Presumably, this also

377 applies to the air-spraying method, as both rely on pressurised water or air driving tissue from

378 the skeleton. Yet the lipid content has been shown to be highest in the mesoglea and 
379 zooxanthellae, as well as the lower half of polyps, which contain the gastrodermis (Al-Sofyani,

380 1994). This is supported by coral tissue histology, which shows high amounts of lipid droplets in

381 the gastrodermal layer of $P$. damicornis, with the epidermal layer containing far less (Luo et al.,

382 2009; Kopp et al., 2015).

383 Secondly, persistent organic material in the denuded skeleton likely includes the organic matrix,

384 for which lipids have been shown to play a significant role in forming (Marin \& Luquet, 2008;

385 Adamiano et al., 2014). Changes in production rates of the organic matrix has been attributed to

386 growth and skeletal deposition (Stolarski, 2003). Furthermore, dynamic changes in lipid

387 compositions of the host gastrodermis are known to reflect the endosymbiotic status (Luo et al.,

388 2009). Since these represent significant processes in coral biology, inclusion of the skeletal

389 component in lipid analyses is imperative in order to gain an accurate insight into a coral's

390 physiological and biochemical condition.

391

392 The persistent lipid in the denuded skeletons also differed in chemical nature from the sprayed

393 tissue. Storage lipids (WAX, TAG, FFA, and 1,2-DAG) are generally associated with energy

394 supply, while structural lipids (AMPL, PE, PS-PI, and PC) are important for the membrane lipid

395 bilayer, and cell membrane stability (Lee, Hagen \& Kattner, 2006). Generally, the storage lipids

396 were found in higher concentrations in the skeleton, while the structural lipids predominated in

397 the tissue for all species except $P$. cylindrica (Fig. 1). The prevalence of storage lipids in the

398 skeleton may be ascribable to a higher proportion of host tissue, including the gastrodermis,

399 persisting deeper into the skeleton, as up to $90 \%$ of storage lipid has been found to reside in the

400 host tissue rather than the zooxanthellae, largely in the form of WAX and TAG (Imbs,

401 Yakovleva \& Pham, 2010; Chen et al., 2015). Underestimation of storage lipids in corals has 
402 ramifications for biological studies, as WAX and TAG are considered to be the most important

403 lipid species with respect to energetic status, which describes the amount of available energy

404 compared to the energy required (Anthony et al., 2009; Imbs, 2013). In particular, concentrations

405 of storage lipids are known to alter in response to coral metabolic requirements (Oku et al.,

406 2002), reproduction (Arai et al., 1993), and zooxanthellae activity (Oku et al., 2002), which are

407 key processes in coral biology and ecology.

408

409 Structural differences extended to the FA composition, which showed marked variation between

410 the denuded skeleton and sprayed tissue, likely reflecting the larger proportion of host tissue in

411 the denuded skeleton and zooxanthellae in the sprayed tissue, as well as functional specialisation

412 of internal and external tissues (Imbs, Yakovleva \& Pham, 2010; Chen et al., 2015). While

413 zooxanthellae densities were not quantified in this work, high zooxanthellae contents have been

414 previously recorded in isolated tissue using the Water-Pik method (Edmunds and Gates 2002).

415 Moreover, although zooxanthellae have been shown to reside within the gastrovascular system

416 (Domart-Coulon et al., 2006), this is largely in the upper portion to gain access to light

417 (Goldberg, 2002), and may thus be more readily removed through air-spraying.

418 Higher total FA concentrations were evident in the skeleton for all species (although this was

419 only statistically significant for $P$. cylindrica and $P$. damicornis), which is reflective of the

420 different lipid class compositions between the two isolates; the skeleton contained higher levels

421 of TAG, which contains three esterified FA, while the sprayed tissue was richer in

422 phospholipids, ST, and AMPL, which possess two or less esterified FA (Lee, Hagen \& Kattner, 423 2006). 
424 Despite a relatively uniform distribution of the major FA classes, SFA, MUFA, and PUFA,

425 between the skeleton and tissue, the individual FA differed substantially between the two

426 isolates. This was illustrated in the separation achieved by PCA between the denuded skeleton

427 and sprayed tissue, and correlates with the findings of Chen et al. (2015); that FA moieties of

428 each lipid species differ between host and symbiont tissues.

429 For example, the FA 14:0, 16:0, and 20:0 contributed largely to the separation of the skeleton

430 from the tissue for most species (Fig. 4), and these generally predominate in host tissues

431 compared to zooxanthellae (Treignier et al., 2008). This is also consistent with the higher

432 abundance of WAX and TAG in the skeleton, since SFA, particularly 16:0, are generally the

433 major FA moieties of these classes in cnidarians (Yamashiro et al., 1999). Furthermore, n-6

434 PUFA were present in higher proportions in the denuded skeleton compared to the sprayed tissue

435 for M. crassotuberculata, P. cylindrica, and P. damicornis (Fig. 2), and these have previously

436 been shown to predominate in coral host tissue (Treignier et al., 2008).

437 The lipid and FA profile of the sprayed tissue may also be specialised to cope with external

438 changes and threats, such as environmental conditions and disease. For instance, 16:OH, 21:0,

$43920: 1 \mathrm{n}-11$, and EPA generally showed stronger associations with the tissue for most species. The

440 fatty alcohol, 16:OH, is recognised as an inhibitor of bacterial fouling in some coral species

441 (Dobretsov et al., 2015), while EPA provides immune function (Bergé \& Barnathan, 2005), as

442 well as photo-protection from ultraviolet radiation (Pilkington et al., 2011). Furthermore, higher

443 levels of phospholipids in the tissue compared to the skeleton for A. millepora, $M$.

444 crassotuberculata, and P. damicornis may reflect the necessity of the outer tissues to cope with

445 seasonal fluctuations in temperature, since regulation of phospholipid composition is suggested

446 to reflect thermal tolerance in corals (Revel et al., 2016). 
447 These results clearly demonstrate compartmentalisation of lipid classes and FA in the internal

448 and external tissues of the coral holobiont. As such, this study conclusively demonstrates the

449 inadequacy of the air-spraying technique to provide accurate identification and subsequent

450 quantification of the total lipid and FA profile of corals, and this extends to all proximate

451 analyses. Use of the intact crushing method for coral biochemical analyses is therefore

452 recommended, since it is robust against tissue loss and accounts for the entire chemical

453 composition of the holobiont.

454 Should studies require additional biometrics rendered impossible by the in toto crushing method,

455 such as zooxanthellae densities and surface area, the use of separate, replicate samples to

456 accommodate these analyses is recommended.

457 


\section{Acknowledgements:}

459 The authors thank the SeaSim team at The Australian Institute of Marine Science (AIMS) and

460 Deakin University's School of Life and Environmental Sciences staff for technical assistance

461 throughout the project. 


\section{References}

463 Ackman RG. 2002. The gas chromatograph in practical analyses of common and uncommon 464 fatty acids for the 21st century. Analytica Chimica Acta 465:175-192.

465 Adamiano A., Goffredo S., Dubinsky Z., Levy O., Fermani S., Fabbri D., Falini G. 2014.

466 Analytical pyrolysis-based study on intra-skeletal organic matrices from Mediterranean

467 corals. Analytical and Bioanalytical Chemistry 406:6021-6033. DOI: 10.1007/s00216-014$468 \quad 7995-1$.

469 Al-Sofyani AA. 1994. Variation in levels and location of lipids in corals tissue of the ROPME $470 \quad$ sea area. KAU: Marine Science 5:121-131.

471 Allemand D., Tambutte E., Girard J., Jaubert J., Tambutté E., Girard J., Jaubert J. 1998. Organic matrix synthesis in the scleractinian coral Stylophora pistillata: role in biomineralization and potential target of the organotin tributyltin. The Journal of experimental biology 201:2001-9. DOI: 10.1007/s13398-014-0173-7.2.

Anthony KRN., Hoogenboom MO., Maynard JA., Grottoli A., Middlebrook R. 2009. Energetics approach to predicting mortality risk from environmental stress: A case study of coral bleaching. Functional Ecology 23:539-550. DOI: 10.1111/j.1365-2435.2008.01531.x.

Arai T., Kato M., Heyward A., Ikeda Y., Lizuka T., Maruyama T. 1993. Lipid composition of postively buoyant eggs of reef building corals. Coral Reefs 12:71-75.

Bachok Z., Mfilinge P., Tsuchiya M. 2006. Characterization of fatty acid composition in healthy and bleached corals from Okinawa, Japan. Coral Reefs 25:545-554. DOI: 10.1007/s00338006-0130-9.

Baumann J., Grottoli AG., Hughes AD., Matsui Y. 2014. Photoautotrophic and heterotrophic carbon in bleached and non-bleached coral lipid acquisition and storage. Journal of 
10.1016/j.jembe.2014.09.017.

Bergé J., Barnathan G. 2005. Fatty acids from lipids of marine organisms: molecular

biodiversity, roles as biomarkers, biologically active compounds, and economical aspects. Advances in Biochemical Engineering/Biotechnology 96:49-125.

Brahmi C., Kopp C., Domart-Coulon I., Stolarski J., Meibom A. 2012. Skeletal growth dynamics

Chen HK., Song SN., Wang LH., Mayfield AB., Chen YJ., Chen WNU., Chen CS. 2015. A linked to trace-element composition in the scleractinian coral Pocillopora damicornis.

Christie W. 2003. Isolation, separation, identification and structural analysis of lipids. In: Lipid Analysis. Bridgewater, United Kingdom: The Oily Press, Bridgewater, UK,.

Conlan J., Jones P., Turchini G., Hall M., Francis D. 2014. Changes in the nutritional composition of captive early-mid stage Panulirus ornatus phyllosoma over ecdysis and larval development. Aquaculture 434:159-170. strategies in mesophotic hard corals using compound specific stable isotope analysis of sterols. Journal of Experimental Marine Biology and Ecology 474:133-141. DOI: 10.1016/j.jembe.2015.10.010.

Dauphin Y., Cuif JP. 1997. Isoelectric properties of the soluble matrices in relation to the chemical composition of some Scleractinian skeletons. Electrophoresis 18:1180-3. DOI: 


$$
\text { 10.1002/elps.1150180726. }
$$

509 Dauphin Y., Cuif JP., Massard P. 2006. Persistent organic components in heated coral aragonitic

510 skeletons-Implications for palaeoenvironmental reconstructions. Chemical Geology 231:26-

511 37. DOI: 10.1016/j.chemgeo.2005.12.010.

512 Davy SK., Allemand D., Weis VM. 2012. Cell biology of cnidarian-dinoflagellate symbiosis.

513 Microbiology and molecular biology reviews : MMBR 76:229-61. DOI: 10.1128/MMBR.05014-11.

Deschaseaux ESM., Deseo MA., Shepherd KM., Jones GB., Harrison PL. 2013. Air blasting as the optimal approach for the extraction of antioxidants in coral tissue. Journal of Experimental Marine Biology and Ecology 448:146-148. DOI: 10.1016/j.jembe.2013.07.002.

Dobretsov S., Al-Wahaibi ASM., Lai D., Al-Sabahi J., Claereboudt M., Proksch P., Soussi B. 2015. Inhibition of bacterial fouling by soft coral natural products. International Biodeterioration and Biodegradation 98:53-58. DOI: 10.1016/j.ibiod.2014.10.019.

Domart-Coulon IJ., Traylor-Knowles N., Peters E., Elbert D., Downs CA., Price K., Stubbs J., McLaughlin S., Cox E., Aeby G., Brown PR., Ostrander GK. 2006. Comprehensive characterization of skeletal tissue growth anomalies of the finger coral Porites compressa.

Edmunds P., Gates R. 2002. Normalizing physiological data for scleractinian corals. Coral reefs 21:193-197. DOI: DOI 10.1007/s00338-002-0214-0.

528 Farre B., Cuif JP., Dauphin Y. 2010. Occurrence and diversity of lipids in modern coral 529 skeletons. Zoology 113:250-257. DOI: 10.1016/j.zool.2009.11.004.

530 Filho CVSM., Dos Santos WPC., De Kikuchi RKP., Hatje V. 2012. Decontamination procedure 
531 for trace elements determination in coral skeleton samples. Microchemical Journal

532 102:123-129. DOI: 10.1016/j.microc.2011.12.007.

533 Goffredo S., Vergni P., Reggi M., Caroselli E., Sparla F., Levy O., Dubinsky Z., Falini G. 2011.

534 The skeletal organic matrix from Mediterranean coral Balanophyllia europaea influences

535 calcium carbonate precipitation. PLOS ONE 6. DOI: 10.1371/journal.pone.0022338.

536 Goldberg WM. 2002. Gastrodermal structure and feeding responses in the scleractinian

537 Mycetophyllia reesi, a coral with novel digestive filaments. Tissue and Cell 34:246-261.

538 DOI: $10.1016 / \mathrm{S} 0040-8166(02) 00008-3$.

539 Hemond EM., Kaluziak ST., Vollmer S V. 2014. The genetics of colony form and function in

540 Caribbean Acropora corals. BMC genomics 15:1133. DOI: 10.1186/1471-2164-15-1133.

541 Hii Y-S., Soo C-L., Liew H-C. 2008. Feeding of scleractinian coral, Galaxea fascicularis, on

542 Artemia salina nauplii in captivity. Aquaculture International 17:363-376. DOI:

$543 \quad 10.1007 / \mathrm{s} 10499-008-9208-4$.

544 Hughes TP., Kerry JT., Álvarez-Noriega M., Álvarez-Romero JG., Anderson KD., Baird AH.,

545 Babcock RC., Beger M., Bellwood DR., Berkelmans R., Bridge TC., Butler IR., Byrne M.,

546 Cantin NE., Comeau S., Connolly SR., Cumming GS., Dalton SJ., Diaz-Pulido G., Eakin

547 CM., Figueira WF., Gilmour JP., Harrison HB., Heron SF., Hoey AS., Hobbs J-PA.,

548 Hoogenboom MO., Kennedy E V., Kuo C-Y., Lough JM., Lowe RJ., Liu G., McCulloch

549 MT., Malcolm HA., McWilliam MJ., Pandolfi JM., Pears RJ., Pratchett MS., Schoepf V.,

550 Simpson T., Skirving WJ., Sommer B., Torda G., Wachenfeld DR., Willis BL., Wilson SK.

5512017 . Global warming and recurrent mass bleaching of corals. Nature 543:373-377. DOI:

$552 \quad 10.1038 /$ nature21707.

553 Imbs AB. 2013. Fatty acids and other lipids of corals: Composition, distribution, and 
554 biosynthesis. Russian Journal of Marine Biology 39:153-168. DOI:

555

556

557

558

559

560

561

562

563

564

565

566

567

568

569

570

571

572

573

574

575

576 10.1134/S1063074013030061.

Imbs AB., Yakovleva IM., Pham LQ. 2010. Distribution of lipids and fatty acids in the zooxanthellae and host of the soft coral Sinularia sp. Fisheries Science 76:375-380. DOI: 10.1007/s12562-009-0213-y.

Johannes RE., Wiebe WJ. 1970. Method for determination of coral tissue biomass and composition. Limnology and Oceanography 15:822-824. DOI: 10.4319/1o.1970.15.5.0822.

Kassambara A., Mundt F. 2016. factoextra: Extract and visualise the results of multivariate data analyses.

Kopp C., Domart-Coulon I., Escrig S., Humbel BM., Hignette M., Meibom A. 2015. Subcellular investigation of photosynthesis-driven carbon and nitrogen assimilation and utilization in the symbiotic reef coral Pocillopora damicornis. mBio 6:1-9. DOI: 10.1128/mBio.0229914. Editor.

Leal MC., Ferrier-Pagès C., Petersen D., Osinga R. 2016. Coral aquaculture: applying scientific knowledge to ex situ production. Reviews in Aquaculture 6:1-18. DOI: 10.1111/raq.12087.

Lee RF., Hagen W., Kattner G. 2006. Lipid storage in marine zooplankton. Marine Ecology Progress Series 307:273-306.

Lesser MP. 2012. Using energetic budgets to assess the effects of environmental stress on corals: are we measuring the right things? Coral Reefs 32:25-33. DOI: 10.1007/s00338-012-0993$\mathrm{X}$.

Lim C-S., Bachok Z., Hii Y-S. 2017. Effects of supplementary polyunsaturated fatty acids on the health of the scleractinian coral Galaxea fascicularis (Linnaeus, 1767). Journal of Experimental Marine Biology and Ecology 491:1-8. DOI: 10.1016/j.jembe.2017.02.009. 
577 Lumley T., Diehr P., Emerson S., Chen L. 2002. The Importance of the Normality Assumption

578 in Large Public Health Data Sets. Annual Reviews of Public Health 23:151-169. DOI:

579 10.1146/annurev.publheath.23.100901.140546.

580 Luo YJ., Wang LH., Chen WNU., Peng SE., Tzen JTC., Hsiao YY., Huang HJ., Fang LS., Chen

581 CS. 2009. Ratiometric imaging of gastrodermal lipid bodies in coral-dinoflagellate

582 endosymbiosis. Coral Reefs 28:289-301. DOI: 10.1007/s00338-008-0462-8.

583 Marin F., Luquet G. 2008. Unusually acidic proteins in biomineralization. Handbook of

584 Biomineralization: Biological Aspects and Structure Formation 1:273-290. DOI:

$585 \quad 10.1002 / 9783527619443 . c h 16$.

586 Oku H., Yamashiro H., Onaga K., Iwasaki H., Takara K. 2002. Lipid distribution in branching

$587 \quad$ coral Montipora digitata. Fisheries Science 68:517-522. DOI: 10.1046/j.1444-

$588 \quad 2906.2002 .00456 . x$.

589 Parrin AP., Netherton SE., Bross LS., McFadden CS., Blackstone NW. 2010. Circulation of $590 \quad$ fluids in the gastrovascular system of a stoloniferan octocoral. Biological Bulletin 219:112-

591 121. DOI: 219/2/112 [pii].

592 Parrish CC., Bodennec G., Gentien P. 1996. Determination of glycoglyerolipids by Chromarod

593 thin-layer chromatography with Iatroscan flame ionization detection. Journal of

$594 \quad$ Chromatography 741:91-97.

595 Pilkington SM., Watson REB., Nicolaou A., Rhodes LE. 2011. Omega-3 polyunsaturated fatty

596 acids: Photoprotective macronutrients. Experimental Dermatology 20:537-543. DOI:

$597 \quad$ 10.1111/j.1600-0625.2011.01294.x.

598 Pisapia C., Anderson K., Pratchett MS. 2014. Intraspecific variation in physiological condition of 599 reef-building corals associated with differential levels of chronic disturbance. PLoS ONE 
9:3-10. DOI: 10.1371/journal.pone.0091529.

601 R Development Core Team. 2016. R: A language and environment for statistical computing. $R$ 602 Foundation for Statistical Computing Vienna, Au.

603 Ramos-Silva P., Kaandorp J., Herbst F., Plasseraud L., Alcaraz G., Stern C., Corneillat M., 604 Guichard N., Durlet C., Luquet G., Marin F. 2014. The skeleton of the staghorn coral 605 Acropora millepora: Molecular and structural characterization. PLoS ONE 9. DOI: 10.1371/journal.pone.0097454.

607 Revel J., Massi L., Mehiri M., Boutoute M., Mayzaud P., Capron L., Sabourault C. 2016.

608 Differential distribution of lipids in epidermis, gastrodermis and hosted Symbiodinium in the 609 sea anemone Anemonia viridis. Comparative Biochemistry and Physiology-Part A :

611 Rodrigues LJ., Grottoli AG., Pease TK. 2008. Lipid class composition of bleached and 612 recovering Porites compressa Dana, 1846 and Montipora capitata Dana, 1846 corals from 613 Hawaii. Journal of Experimental Marine Biology and Ecology 358:136-143. DOI: 10.1016/j.jembe.2008.02.004.

615 Rodríguez-Troncoso AP., Carpizo-Ituarte E., Leyte-Morales GE., Chi-Barragán G., Tapia616 Vázquez O. 2011. Sexual reproduction of three coral species from the Mexican South 617 Pacific. Marine Biology 158:2673-2683. DOI: 10.1007/s00227-011-1765-9.

618 RStudio Team. 2015. RStudio: Integrated Development Environment for R.

619 Sajiki J., Takahashi H., Takahashi K. 1995. Impact of vinegar acetic-acid on hydrolysis and 620 oxidation of lipids in tissues of the oyster, Crassostrea-gigas, at 37-degrees. J.Agr.Food 621 Chem. IrJournal of Agricultural and Food Chemistry 43:1467-1471.

622 Saunders SM., Radford B., Bourke SA., Thiele Z., Bech T., Mardon J. 2005. A rapid method for 
623 determining lipid fraction ratios of hard corals under varying sediment and light regimes.

624 Environmental Chemistry 2:331-336. DOI: 10.1071/EN05043.

625 Seemann J., Sawall Y., Auel H., Richter C. 2013. The use of lipids and fatty acids to measure the 626 trophic plasticity of the coral Stylophora subseriata. Lipids 48:275-86. DOI:

627 10.1007/s11745-012-3747-1.

Stolarski J. 2003. Three-dimensional micro- and nanostructural characteristics of the scleractinian coral skeleton: A biocalcification proxy. Acta Palaeontologica Polonica

631

Szmant AM., Gassman NJ. 1990. The effects of prolonged "bleaching" on the tissue biomass and 632 reproduction of the reef coral Montastrea annularis. Coral Reefs 8:217-224. DOI:

633 10.1007/BF00265014.

634 Tambutté S., Tambutté E., Zoccola D., Allemand D. 2007. Organic matrix and biomineralization 635 of scleractinian corals. Handbook of Biomineralization: Biological Aspects and Structure Formation 1:243-259. DOI: 10.1002/9783527619443.ch14.

637 Towle EK., Enochs IC., Langdon C. 2015. Threatened Caribbean coral is able to mitigate the 638 adverse effects of ocean acidification on calcification by increasing feeding rate. PLoS ONE 10:1-17. DOI: 10.1371/journal.pone.0123394.

640 Treignier C., Grover R., Ferrier-Pagès C., Tolosa I. 2008. Effect of light and feeding on the fatty 641 acid and sterol composition of zooxanthellae and host tissue isolated from the scleractinian 642 coral Turbinaria reniformis. Limnology and Oceanography 53:2702-2710. DOI:

$643 \quad 10.4319 / 10.2008 .53 .6 .2702$.

644 Veal CJ., Carmi M., Fine M., Hoegh-Guldberg O. 2010. Increasing the accuracy of surface area 645 estimation using single wax dipping of coral fragments. Coral Reefs 29:893-897. DOI: 
647 Veron SS. 2000. Corals of the world. Townsville: Australian Institute of Marine Science.

648 Ward S. 1995. Two patterns of energy allocation for growth, reproduction and lipid storage in 649 the scleractinian coral Pocillopora damicornis. Coral Reefs 14:87-90.

650 Wickham H. 2009. ggplot2: Elegant Graphics for Data Analysis. New York: Springer-Verlag. 651 Work TM., Aeby GS. 2010. Wound repair in Montipora capitata. Journal of Invertebrate 652 Pathology 105:116-119. DOI: 10.1016/j.jip.2010.05.009.

653 Yamashiro H., Oku H., Higa H., Chinen I., Sakai K. 1999. Composition of lipids, fatty acids and 654 sterols in Okinawan corals. Comparative Biochemistry and Physiology - B Biochemistry 655 and Molecular Biology 122:397-407. DOI: 10.1016/S0305-0491(99)00014-0.

656 Yost DM., Wang LH., Fan TY., Chen CS., Lee RW., Sogin E., Gates RD. 2013. Diversity in 657 skeletal architecture influences biological heterogeneity and Symbiodinium habitat in corals. 658 Zoology 116:262-269. DOI: 10.1016/j.zool.2013.06.001. 


\section{Figures}

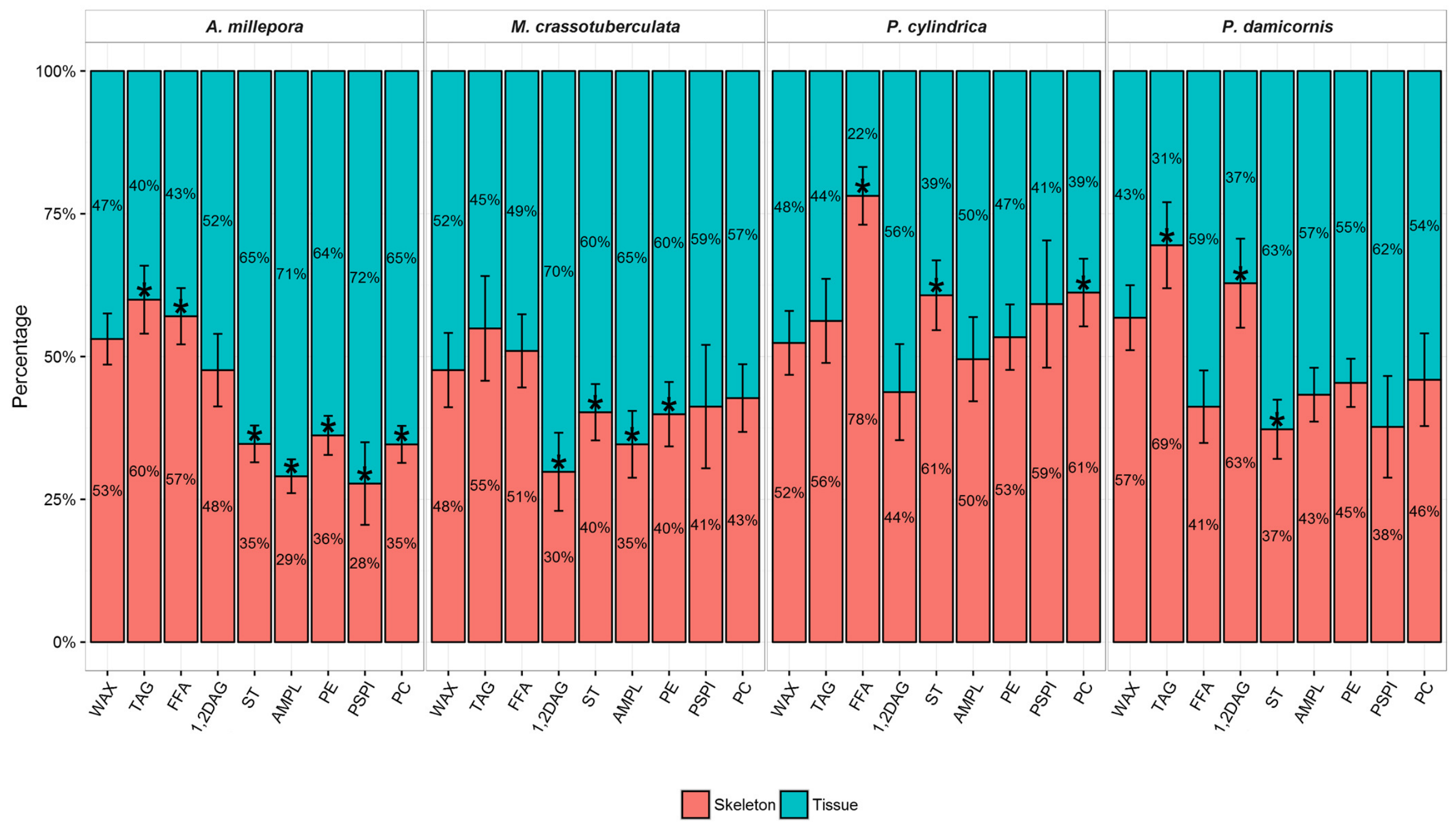




\section{Fig. 1}

662 Lipid class composition of denuded skeleton and isolated tissue of four scleractinian species prepared with the air-spraying method - relative contribution (\% 663 total)

664 Values are presented as means $\pm \operatorname{SEM}(\mathrm{n}=20) . *$ denote significant differences between stacked bars within each species (tissue vs skeleton) $(P<0.05)$. 


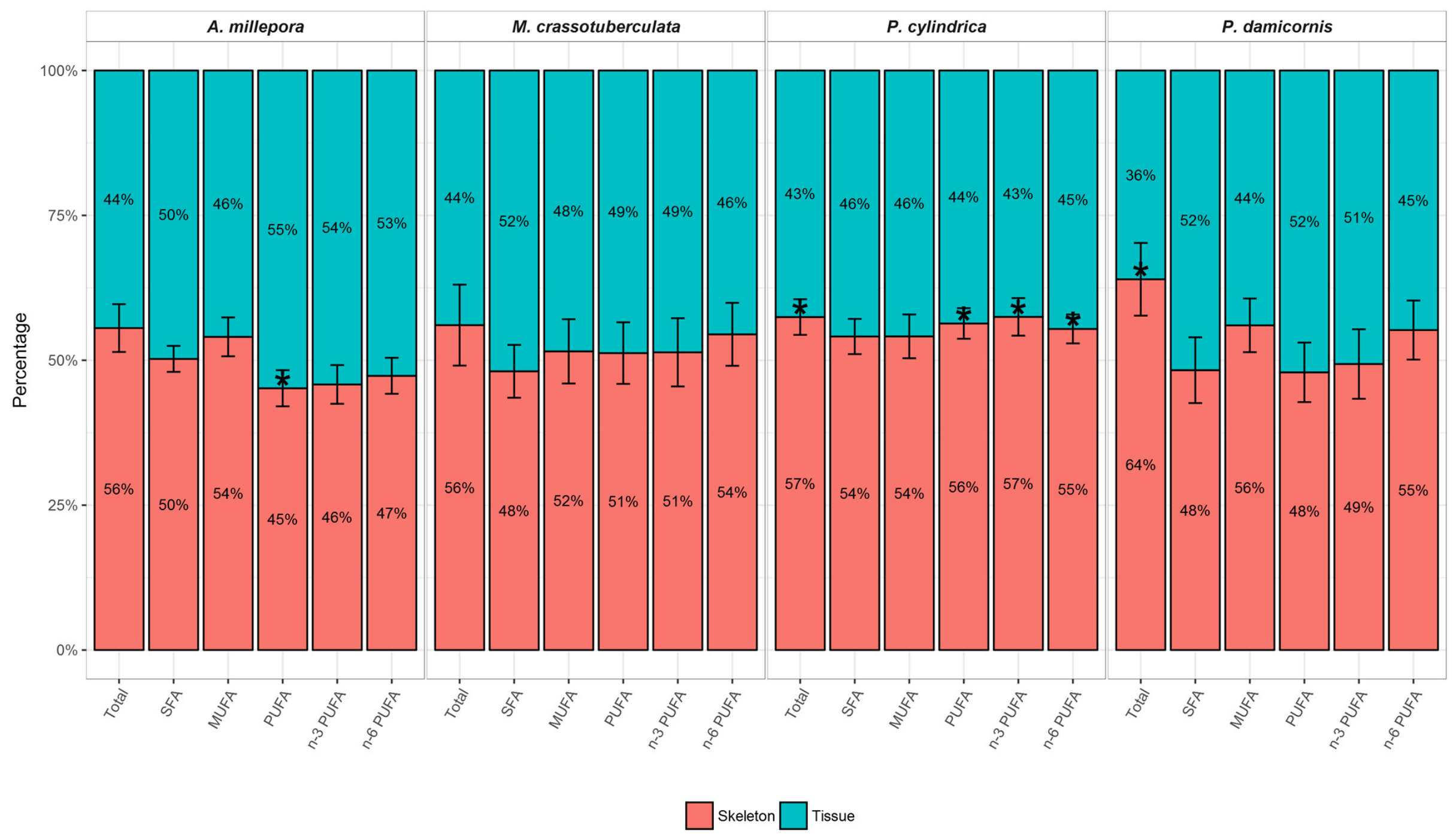

666 Fig. 2 
667 Fatty acid composition of denuded skeleton and isolated tissue of four scleractinian species prepared with the air-spraying method - relative contribution (\% 668 total)

669 Values are presented as means $\pm \operatorname{SEM}(\mathrm{n}=20) .{ }^{*}$ denote significant differences between stacked bars within each species (tissue vs skeleton) $(\mathrm{P}<0.05)$. 
a

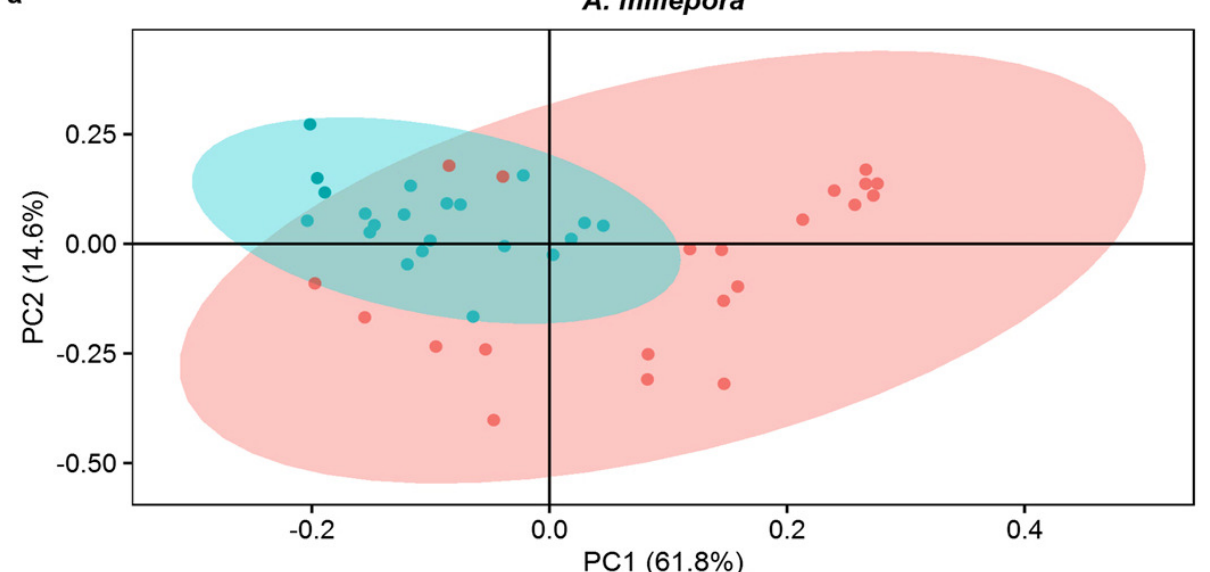

c
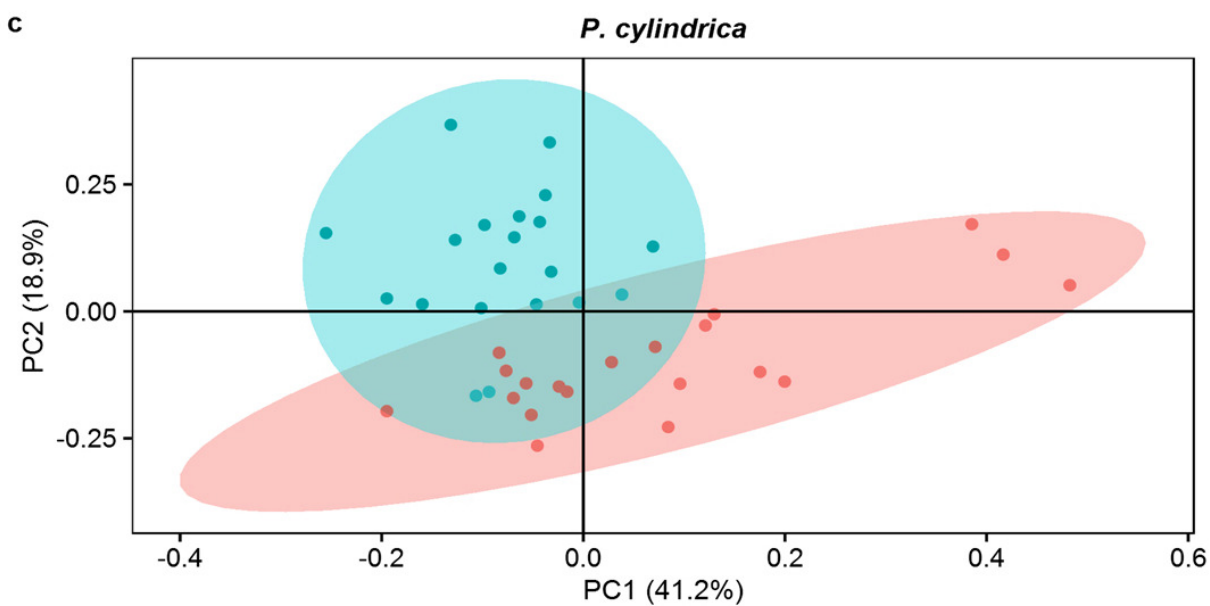

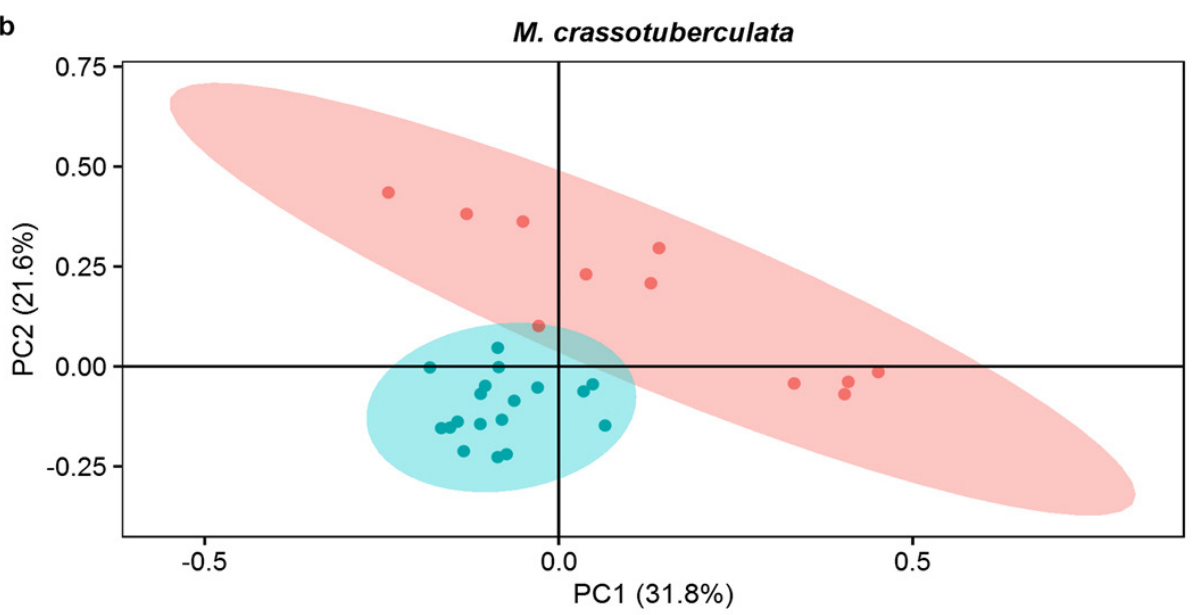

d

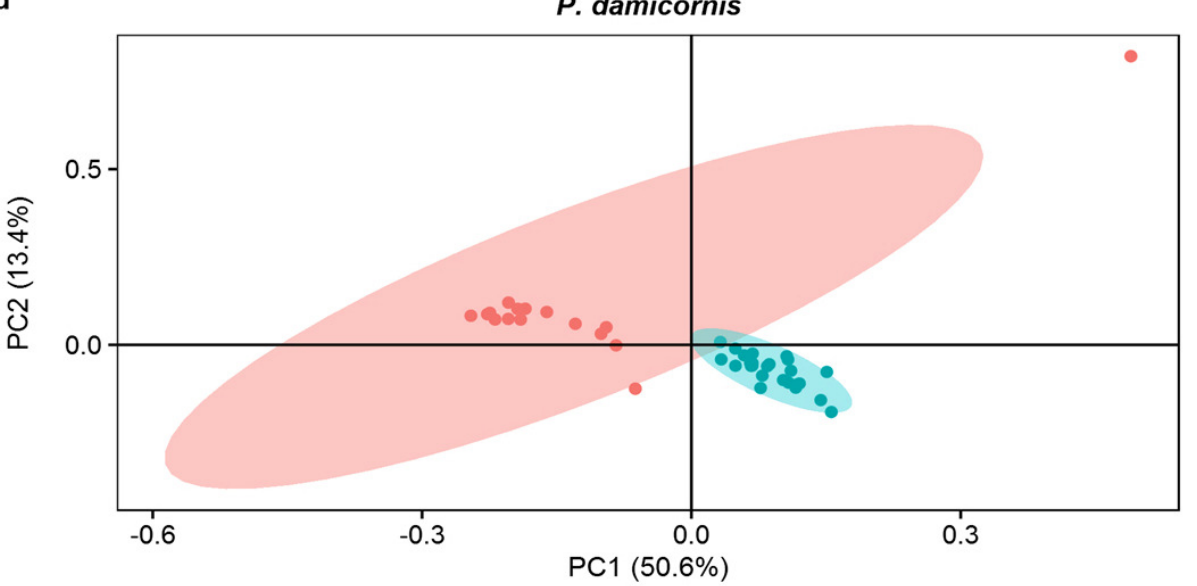

670

671

672
Fig. 3

Score plot of principal component analysis of fatty acid and fatty alcohol profiles (based on \% fatty acids) of denuded skeleton and isolated tissue of four scleractinian species prepared with the air-spraying method (ellipses show $95 \%$ confidence intervals). 

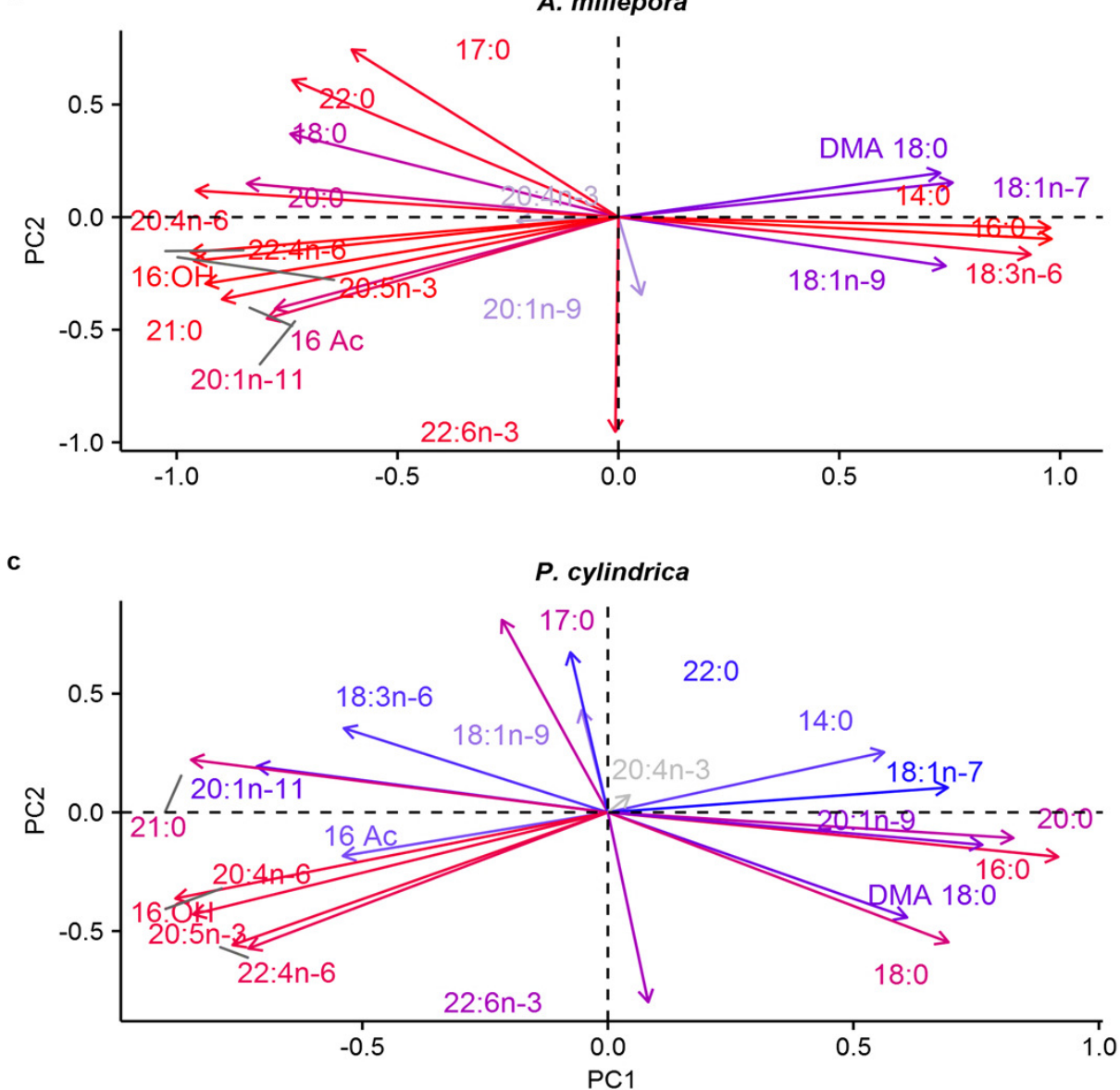
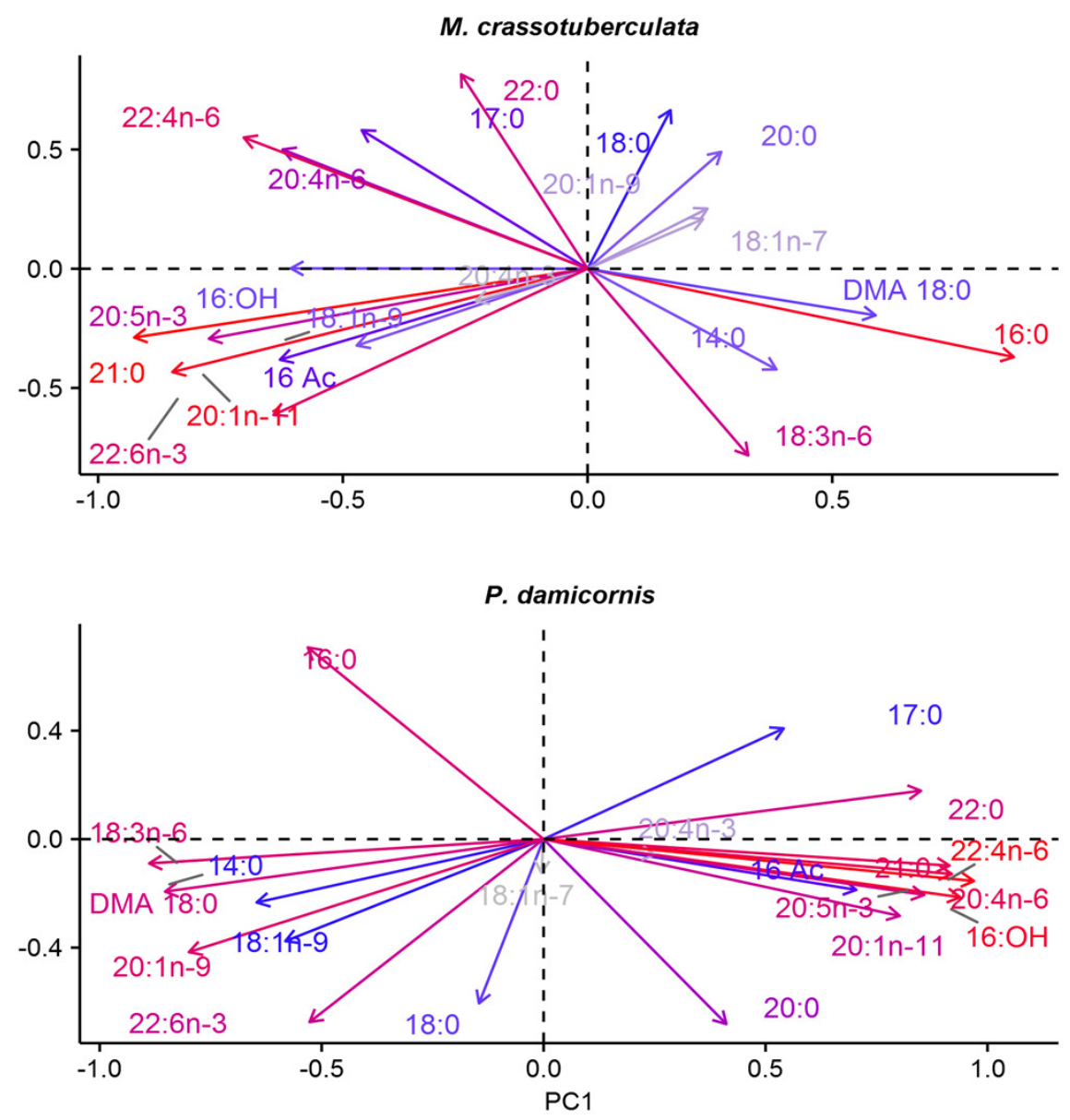

Contribution

\section{Fig. 4}

Principal component analysis loading plot of fatty acid and fatty alcohol profiles of denuded skeleton and isolated tissue of four scleractinian species prepared with the air-spraying method (\% fatty acids). Colour gradient shows percentage contribution to overall variance. Fatty alcohol abbreviations: 16 Ac= Hexadecyl acetate, DMA 18:0=1,1-dimethoxyoctadecane, 16:OH=1-hexadecanol. 


\section{Table 1}

Proximate composition of four scleractinian species using air-spraying and in toto crushing sample preparation techniques.

681 Intact: samples prepared with in toto crushing method, Recombined: combined results of isolated skeleton and tissue prepared with the air-spraying method,

682 Skeleton: denuded skeleton samples, Tissue: isolated tissue samples.

\begin{tabular}{|ccc|ccc|}
\hline & & CRUSH & \multicolumn{3}{c|}{ AIR-SPRAY } \\
\hline Species & $\left(m g g\right.$ sample $\left.{ }^{-1}\right)$ & Intact & Recombined & Skeleton & Tissue \\
\hline & Total sample & $1000 \pm 0.00$ & $1000 \pm 0.00$ & $960 \pm 1.80^{\wedge}$ & $40.1 \pm 1.80^{\wedge}$ \\
A. millepora & Ash & $944 \pm 2.30$ & $943 \pm 2.20$ & $923 \pm 2.20^{\wedge}$ & $19.8 \pm 2.20^{\wedge}$ \\
& Organic & $66.1 \pm 2.30$ & $57.1 \pm 2.20$ & $36.3 \pm 2.20^{\wedge}$ & $21.3 \pm 2.20^{\wedge}$ \\
& Lipid & $9.93 \pm 0.64^{*}$ & $6.20 \pm 0.61^{*}$ & $2.62 \pm 0.61^{\wedge}$ & $3.58 \pm 0.61^{\wedge}$ \\
& Lipid $\left(m g g A F D W^{-1}\right)$ & $178 \pm 10.6^{*}$ & $110 \pm 11.6^{*}$ & $47.5 \pm 11.6^{\wedge}$ & $62.5 \pm 11.6^{\wedge}$ \\
\hline & Total sample & $1000 \pm 0.00$ & $1000 \pm 0.00$ & $967 \pm 2.10^{\wedge}$ & $33.3 \pm 2.10^{\wedge}$ \\
M. crassotuberculata & Ash & $947 \pm 2.30$ & $950 \pm 2.50$ & $934 \pm 2.50^{\wedge}$ & $16.2 \pm 2.50^{\wedge}$ \\
& Organic & $53.2 \pm 2.30$ & $50.4 \pm 2.20$ & $33.9 \pm 2.20^{\wedge}$ & $16.1 \pm 2.20^{\wedge}$ \\
& Lipid & $6.42 \pm 0.52^{*}$ & $4.30 \pm 0.50^{*}$ & $1.82 \pm 0.50$ & $2.48 \pm 0.50$ \\
& Lipid $\left(m g g A F D W^{-1}\right)$ & $122 \pm 10.3^{*}$ & $87.7 \pm 9.80^{*}$ & $38.1 \pm 9.80$ & $49.6 \pm 9.80$ \\
\hline P. cylindrica & Total sample & $1000 \pm 0.00$ & $1000 \pm 0.00$ & $989 \pm 0.80^{\wedge}$ & $11.2 \pm 0.80^{\wedge}$ \\
& Ash & $949 \pm 2.40$ & $951 \pm 1.80$ & $947 \pm 1.80^{\wedge}$ & $3.80 \pm 1.80^{\wedge}$ \\
& Organic & $51.1 \pm 2.30$ & $49.4 \pm 2.20$ & $36.6 \pm 1.80^{\wedge}$ & $12.4 \pm 1.80^{\wedge}$ \\
& Lipid & $3.44 \pm 0.21^{*}$ & $2.5 \pm 0.33^{*}$ & $1.26 \pm 0.33$ & $1.24 \pm 0.33$ \\
& Lipid $\left(m g g A F D W^{-1}\right)$ & $67.8 \pm 5.20$ & $51.1 \pm 6.50$ & $26.3 \pm 6.50$ & $24.8 \pm 6.50$ \\
\hline P. damicornis & Total sample & $1000 \pm 0.00$ & $1000 \pm 0.00$ & $979 \pm 0.80^{\wedge}$ & $21.1 \pm 0.80^{\wedge}$ \\
& Ash & $954 \pm 2.60$ & $959 \pm 1.30$ & $950 \pm 1.30^{\wedge}$ & $8.63 \pm 1.30^{\wedge}$ \\
& Organic & $46.2 \pm 2.30$ & $41.1 \pm 2.20$ & $34.3 \pm 1.30^{\wedge}$ & $6.72 \pm 1.30^{\wedge}$ \\
& Lipid & $2.74 \pm 0.22^{*}$ & $1.8 \pm 0.24^{*}$ & $0.76 \pm 0.24$ & $1.04 \pm 0.24$ \\
& Lipid $\left(m g g A F D W^{-1}\right)$ & $61.3 \pm 4.30^{*}$ & $45.1 \pm 5.00^{*}$ & $19.6 \pm 5.00$ & $25.5 \pm 5.00$ \\
\hline
\end{tabular}




\section{Table 2}

686 Lipid class composition of intact and recombined samples of four scleractinian species prepared using air-spraying and in toto crushing sample preparation techniques. Intact: samples prepared with crushing method, Recombined: combined results of isolated skeleton and tissue prepared with the air-spraying method

\begin{tabular}{|c|c|c|c|c|c|c|c|c|}
\hline \multirow[t]{2}{*}{$\left(m g g\right.$ lipid $\left.^{-1}\right)$} & \multicolumn{2}{|c|}{ A. millepora } & \multicolumn{2}{|c|}{ M. crassotuberculata } & \multicolumn{2}{|c|}{ P. cylindrica } & \multicolumn{2}{|c|}{ P. damicornis } \\
\hline & Intact & Recombined & Intact & Recombined & Intact & Recombined & Intact & Recombined \\
\hline WAX & $123 \pm 6.70$ & $112 \pm 6.39$ & $85.9 \pm 4.79$ & $104 \pm 22.4$ & $88.1 \pm 2.60$ & $98.1 \pm 5.05$ & $95.6 \pm 2.92$ & $104 \pm 7.20$ \\
\hline TAG & $194 \pm 32.9$ & $172 \pm 32.3$ & $170 \pm 33.0$ & $143 \pm 29.6$ & $70.7 \pm 5.18$ & $75.2 \pm 8.78$ & $189 \pm 25.9$ & $205 \pm 32.6$ \\
\hline FFA & $41.8 \pm 3.17^{*}$ & $27.0 \pm 1.99 *$ & $21.5 \pm 1.90^{*}$ & $32.9 \pm 2.81^{*}$ & $36.1 \pm 10.6$ & $28.0 \pm 3.05$ & $45.8 \pm 3.04 *$ & $30.1 \pm 3.49 *$ \\
\hline 1,2 DAG & $74.2 \pm 7.57$ & $82.1 \pm 7.37$ & $97.1 \pm 5.27$ & $83.3 \pm 10.4$ & $112 \pm 2.06$ & $109 \pm 11.4$ & $82.2 \pm 7.95$ & $76.8 \pm 10.2$ \\
\hline ST & $80.1 \pm 4.38$ & $71.7 \pm 4.09$ & $74.7 \pm 3.89$ & $77 \pm 4.81$ & $79.2 \pm 4.31$ & $86.3 \pm 5.52$ & $71.7 \pm 2.84$ & $80.8 \pm 6.87$ \\
\hline AMPL & $175 \pm 11.0$ & $184 \pm 10.9$ & $173 \pm 15.6$ & $210 \pm 16.2$ & $171 \pm 6.63$ & $185 \pm 9.82$ & $134 \pm 5.62 *$ & $166 \pm 11.4^{*}$ \\
\hline PE & $84.4 \pm 7.02 *$ & $106 \pm 6.41^{*}$ & $118 \pm 10.4$ & $114 \pm 6.25$ & $120 \pm 1.67$ & $133 \pm 9.6$ & $99.0 \pm 3.85$ & $110 \pm 7.96$ \\
\hline PSPI & $104 \pm 14.8$ & $102 \pm 14.1$ & $115 \pm 18.6$ & $96.7 \pm 17.0$ & $153 \pm 13.4^{*}$ & $104 \pm 18.3^{*}$ & $122 \pm 14.6$ & $109 \pm 13.6$ \\
\hline PC & $123 \pm 7.49$ & $135 \pm 7.27$ & $133 \pm 8.79$ & $126 \pm 8.07$ & $151 \pm 2.85$ & $142 \pm 13.0$ & $123 \pm 5.97$ & $105 \pm 10.2$ \\
\hline LPC & $\mathrm{nd}^{*}$ & $8.97 \pm 4.21^{*}$ & $12.1 \pm 6.52$ & $12.6 \pm 8.58$ & $19.1 \pm 8.75$ & $39.4 \pm 8.52$ & $38.1 \pm 9.51^{*}$ & $14.1 \pm 6.72 *$ \\
\hline$\sum$ STORAGE & $433 \pm 32.8$ & $393 \pm 33.9$ & $375 \pm 34.2$ & $363 \pm 33.5$ & $307 \pm 9.76$ & $310 \pm 17.1$ & $412 \pm 29.0$ & $415 \pm 28.3$ \\
\hline$\sum$ STRUCTURAL & $567 \pm 32.8$ & $607 \pm 33.9$ & $625 \pm 34.2$ & $637 \pm 33.5$ & $693 \pm 9.76$ & $690 \pm 17.1$ & $588 \pm 29.0$ & $585 \pm 28.3$ \\
\hline
\end{tabular}




\section{Table 3}

691 Fatty acid and fatty alcohol composition of intact and recombined samples of four scleractinian species prepared using air-spraying and in toto crushing sample preparation techniques. Intact: samples prepared with crushing method, Recombined: combined results of isolated skeleton and tissue prepared with the air-

\begin{tabular}{|c|c|c|c|c|c|c|c|c|}
\hline \multirow[t]{2}{*}{ (\% fatty acids) } & \multicolumn{2}{|c|}{ A. millepora } & \multicolumn{2}{|c|}{ M. crassotuberculata } & \multicolumn{2}{|c|}{ P. cylindrica } & \multicolumn{2}{|c|}{ P. damicornis } \\
\hline & Intact & Recombined & Intact & Recombined & Intact & Recombined & Intact & Recombined \\
\hline 16 Ac & $0.42 \pm 0.03$ & $0.47 \pm 0.03$ & $0.21 \pm 0.03$ & $0.18 \pm 0.03$ & $0.19 \pm 0.03$ & $0.18 \pm 0.04$ & $0.38 \pm 0.02$ & $0.40 \pm 0.04$ \\
\hline DMA 18:0 & $1.53 \pm 0.16$ & $1.20 \pm 0.14$ & $0.20 \pm 0.02$ & $0.23 \pm 0.04$ & $2.67 \pm 0.21$ & $2.88 \pm 0.24$ & $2.00 \pm 0.19$ & $2.26 \pm 0.36$ \\
\hline 16:OH & $5.68 \pm 0.80$ & $6.06 \pm 1.04$ & $2.23 \pm 0.53$ & $2.02 \pm 0.67$ & $0.88 \pm 0.35$ & $0.38 \pm 0.18$ & $2.77 \pm 0.38$ & $2.83 \pm 0.58$ \\
\hline$\sum$ Fatty Alcohol & $7.77 \pm 0.62$ & $8.07 \pm 0.88$ & $2.65 \pm 0.53$ & $2.57 \pm 0.64$ & $3.79 \pm 0.42$ & $4.22 \pm 0.31$ & $5.63 \pm 0.37$ & $6.02 \pm 0.48$ \\
\hline $14: 0$ & $3.55 \pm 0.20$ & $3.72 \pm 0.18$ & $3.38 \pm 0.22$ & $3.71 \pm 0.30$ & $1.97 \pm 0.26$ & $2.17 \pm 0.37$ & $3.19 \pm 0.18$ & $3.60 \pm 0.19$ \\
\hline $16: 0$ & $29.9 \pm 1.78$ & $33.7 \pm 1.38$ & $34.2 \pm 2.70$ & $37.8 \pm 2.77$ & $24.2 \pm 0.78^{*}$ & $27.3 \pm 1.10^{*}$ & $32.2 \pm 0.83$ & $31.7 \pm 1.88$ \\
\hline $18: 0$ & $11.6 \pm 0.53$ & $12.4 \pm 0.76$ & $8.92 \pm 0.34$ & $9.65 \pm 0.29$ & $10.5 \pm 0.69$ & $12.2 \pm 0.46$ & $13.8 \pm 0.47^{*}$ & $16.2 \pm 0.53 *$ \\
\hline$\sum$ SFA & $48.5 \pm 1.24 *$ & $53.5 \pm 0.75^{*}$ & $51.9 \pm 2.42$ & $56.4 \pm 2.22$ & $42.4 \pm 1.35^{*}$ & $47.9 \pm 1.42 *$ & $52.7 \pm 0.94$ & $55.8 \pm 1.43$ \\
\hline $18: 1 n-9$ & $3.92 \pm 0.32$ & $4.70 \pm 0.24$ & $3.06 \pm 0.16^{*}$ & $5.26 \pm 0.51^{*}$ & $5.98 \pm 0.21^{*}$ & $7.60 \pm 0.24^{*}$ & $5.98 \pm 0.32 *$ & $7.08 \pm 0.38^{*}$ \\
\hline $20: 1 n-11$ & $3.85 \pm 0.31$ & $3.26 \pm 0.22$ & $3.85 \pm 0.50$ & $3.79 \pm 0.43$ & $4.19 \pm 0.39^{*}$ & $2.97 \pm 0.20^{*}$ & $1.99 \pm 0.11$ & $1.75 \pm 0.12$ \\
\hline$\sum$ MUFA & $12.6 \pm 0.18$ & $12.5 \pm 0.24$ & $11.0 \pm 0.38^{*}$ & $14.6 \pm 1.00^{*}$ & $14.3 \pm 1.13$ & $13.6 \pm 0.58$ & $15.6 \pm 0.45$ & $16.6 \pm 0.79$ \\
\hline $20: 5 n-3$ & $11.1 \pm 0.93^{*}$ & $8.31 \pm 0.64^{*}$ & $4.25 \pm 0.47$ & $3.11 \pm 0.35$ & $8.96 \pm 0.22 *$ & $7.03 \pm 0.33^{*}$ & $3.83 \pm 0.28^{*}$ & $2.57 \pm 0.31^{*}$ \\
\hline $22: 6 n-3$ & $3.75 \pm 0.08^{*}$ & $3.12 \pm 0.08^{*}$ & $2.49 \pm 0.17$ & $2.07 \pm 0.14$ & $7.50 \pm 0.33^{*}$ & $5.71 \pm 0.35^{*}$ & $7.12 \pm 0.16$ & $6.34 \pm 0.44$ \\
\hline $18: 3 n-6$ & $3.55 \pm 0.19$ & $3.50 \pm 0.19$ & $4.21 \pm 0.19$ & $3.69 \pm 0.24$ & $1.58 \pm 0.14$ & $1.53 \pm 0.12$ & $1.32 \pm 0.04$ & $1.28 \pm 0.09$ \\
\hline $20: 4 n-6$ & $4.53 \pm 0.52$ & $3.60 \pm 0.41$ & $7.26 \pm 0.57^{*}$ & $4.68 \pm 0.47^{*}$ & $7.43 \pm 0.40$ & $6.91 \pm 0.57$ & $4.38 \pm 0.42 *$ & $2.28 \pm 0.32 *$ \\
\hline $22: 4 n-6$ & $3.16 \pm 0.36$ & $2.62 \pm 0.31$ & $9.83 \pm 1.21$ & $7.00 \pm 1.14$ & $7.45 \pm 0.31$ & $7.01 \pm 0.53$ & $3.20 \pm 0.31$ & $2.97 \pm 0.40$ \\
\hline$\sum$ PUFA & $31.2 \pm 1.86^{*}$ & $26.0 \pm 1.38^{*}$ & $34.4 \pm 2.60^{*}$ & $26.5 \pm 2.21^{*}$ & $39.5 \pm 0.88^{*}$ & $34.3 \pm 1.52 *$ & $26 \pm 0.97^{*}$ & $21.5 \pm 0.82 *$ \\
\hline$\sum$ n-3 PUFA & $17.6 \pm 1.14^{*}$ & $13.7 \pm 0.76^{*}$ & $8.53 \pm 0.81$ & $6.59 \pm 0.65$ & $19.6 \pm 0.65^{*}$ & $14.8 \pm 0.63^{*}$ & $12.6 \pm 0.35^{*}$ & $10.3 \pm 0.51^{*}$ \\
\hline$\sum$ n-6 PUFA & $13.4 \pm 0.71$ & $12.2 \pm 0.61$ & $25.4 \pm 1.79^{*}$ & $19.5 \pm 1.63^{*}$ & $19.5 \pm 0.98$ & $19.5 \pm 1.29$ & $13.3 \pm 0.71^{*}$ & $11.1 \pm 0.59^{*}$ \\
\hline Total $^{\wedge}$ (\% lipid) & $34.9 \pm 2.84^{*}$ & $26.1 \pm 2.21^{*}$ & $30.0 \pm 3.36^{*}$ & $18.7 \pm 2.06^{*}$ & $33.4 \pm 3.14^{*}$ & $16.4 \pm 0.78^{*}$ & $25.8 \pm 3.10$ & $29.2 \pm 2.16$ \\
\hline
\end{tabular}


694 Values are presented as means $\pm \operatorname{SEM}(\mathrm{n}=20)$. Fatty alcohol abbreviations: $16 \mathrm{Ac}=$ Hexadecyl acetate, DMA 18:0=1,1-dimethoxyoctadecane, 16:OH= 1-

695 hexadecanol. *s indicate significant differences between intact and recombined samples within each species $(\mathrm{P}<0.05)$. ${ }^{\wedge}$ Total value also includes the minor fatty acids: 8:0, 10:0, 12:0, 15:0, 17:0, 20:0, 21:0, 22:0, 24:0, 14:1n-5, 15:1n-5, 16:1n-7, 17:1n-7, 18:1n-7, 18:1n-7trans, 18:1n-9trans, 20:1n-9, 22:1n-9, 24:1n-9, 